\title{
Türkiye’nin En Çok Yabancı Turist Ağırlayan Destinasyonların Imajına Yönelik Bir Araştırma
}

\author{
Mutlu Kaya ${ }^{1 *}$ (iD \\ ${ }^{1}$ Ondokuz Mayıs Üniversitesi, Turizm Fakültesi, mutlu.kaya@omu.edu.tr, ORCID: 0000-0001-9165-0110
}

Öz

\begin{abstract}
Insanların zihnindeki mekân imajları turizm davranışını ve hedef destinasyon seçimini belirleyen en önemli etkenlerden biridir. Bu imajların ve daha çok hangi yollarla elde edildiğinin bilinmesi turizm planlamaları açısından oldukça önemlidir. Bu çalışmada Amerikalı bireylerin Türkiye’nin en fazla turist çeken şehirleri olan istanbul ve Antalya'nın destinasyon imajına yönelik görüşleri ve bu destinasyonlara ait algıları belirlenmeye çalışılmıştır. Araştırmada nicel yöntem kullanılmış olup veri toplama tekniği olarak anket kullanılmıştır. Veri toplama işlemi 1-5 Temmuz 2020 tarihleri arasında Amazon Mekanik Turk çevrimiçi veri toplama sitesi aracılığıyla gerçekleştirilmiş, eksik ve hatalı yanıtlanmış anketler elendikten sonra 416 anket analize uygun bulunmuştur. Elde edilen bulgulara göre her iki şehrin de destinasyon imajına ait unsurlar, beşüzerinden üç ve üzerinde ortalama almıştır. istanbul'un destinasyon imajına yönelik en yüksek ortalamayı alan unsur kültürel çekiciliklerin varlığı iken Antalya'nın destinasyon imajına yönelik en yüksek ortalamayı alan unsur tarihi çekiciliklerin varlığı olmuştur. En düşük ortalamayı alan unsur ise her iki şehir için de şehirlerin sıkıcı olması olmuştur. Her iki destinasyona ait algıların ve destinasyon imajlarının ağırlıklı olarak televizyonda izledikleri haberlerden, internet ve sosyal medyadaki paylaşımlardan oluştuğu belirlenmiştir. Uygulanan Tek Yönlü Varyans Analizi sonucuna göre istanbul'u ve Antalya'yı hiç ziyaret etmemiş turistlerin, bu şehirlere yönelik destinasyon imaj algısının şehirlerden en az birini ziyaret etmiş turistlere göre daha düşük olduğu belirlenmiştir.
\end{abstract}

Anahtar Kelimeler: Antalya, İstanbul, Destinasyon Imajı, Zihin Haritası

\section{A Research on Image of Destinations in Turkey that Welcome Most Foreign Tourists}

Abstract

The image of the place in people's minds is one of the most effective factors that determines travel behavior and destination choice. In terms of tourism planning, it is very important to know these images and how they are obtained. In this study, it was tried to be determined American travelers' perception and destination images of Istanbul and Antalya which were the most visited destination in Turkey. The quantitative research method was preferred and survey as data collection technique was used in the study. Data collection was carried out between 1-5 July 2020 from Amazon Mechanical Turk which was an online data collection platform. In total, 416 eligible survey were identified for analysis after the elimination of incomplete or incorrectly answered surveys. According to the findings, the elements of the destination image of both cities received an average of three and above out of five. The element of istanbul's image that had the highest score was the presence of cultural attractions and the element of Antalya's image that had the highest score was the presence of historical attractions. The lowest score for both cities belongs to being a bored city. The images have been built based on what they see on the news on TV, Internet, and social media. According to the One Way Anova, the tourists' perception who have never visited istanbul or Antalya towards the destination image of these cities was determined lower than the tourists' perception who have visited at least one of them.

Keywords: Antalya, Istanbul, Destination Image, Mind Map.

\section{Araştırma Makalesi}

Cilt 5, Sayı 1, 2021

ss. $117-130$

Gönderim : 31.01 .2021

1. Düzeltme: 23.02 .2021

Kabul Tarihi: 17.03.2021

Research Article

Vol 5, No 1, 2021

pp. $117-130$

Received : 31.01 .2021

Revision1: 23.02.2021

Accepted: 17.03.2021

\section{Önerilen Atıf/Suggested Citation}

Kaya, M. (2021). Türkiye'nin En Çok Yabancı Turist Ağırlayan Destinasyonların İmajına Yönelik Bir Araştırma. Güncel Turizm Araştırmaları Dergisi, 5(1), 117-130.

*Sorumlu yazar e-posta: mutlu.kaya@omu.edu.tr 


\section{GíRiş}

Mekansal davranış; kökenleri, mesafeleri, hedefleri, yönleri ve oluşum frekansları ile karakterize edilebilen hareket kalıplarını ifade etmektedir. Örneğin, insanlar sürekli olarak ziyaret edilecek yerler ve oraya nasıl gidileceği hakkında kararlar alır. Bu nedenle, turizm endüstrisi, bireylerin mekânın bilişsel temsilini manipüle edecek ve olumlu yönde etkileyecek pazarlama materyalleri üretmek için çok çalışmaktadır (Lankford, Scholl, Lankford ve Williams, 2005). Turistler, kişisel özellikleri (yaş, meslek, medeni durum vb.), zevkleri, kültürleri, inançlarının etkisiyle kişilerarası iletişim, eğitim, basılı yayın ya da internet siteleri ve sosyal medya aracılığıyla destinasyonlar hakkında zihinlerinde bir imaj oluşturur ve bu imajları zihin haritalarında ilgili bölümlere yerleştirir. Bu haritaya yerleştirilen imaj, tatil yeri seçimi konusunda verilecek kararda oldukça etkili olmaktadır. Ülkeler ve şehirler bu imaja katkı yapmak ya da olumlu yönde değiştirmek için birçok çalışma yapmaktadır. Bu çalışmaların daha verimli olması için insanların bu imajları daha çok hangi yollarla elde ettiği ve bunların etkisinin bilinmesi büyük öneme sahiptir. Çünkü bu bilgiler turizm davranışını ve hedef seçim sürecini anlamada oldukça önemlidir.

İnsanın karar verme mekanizmasında etkin rol oynayan çevre etkileri, tecrübeler, beklentiler, önyargılar ve bunların etrafında örülmüş davranış kalıpları ile mekân arasındaki ilişki davranışsal coğrafya yaklaşımı ile incelenmektedir. Kişilerin çevreyi nasıl algıladıkları, buna bağlı olarak gelişen düşünce sistemleri ve her ikisinin insan davranışları üzerindeki etkileri davranışsal coğrafyanın konusunu oluşturmaktadır (Temurçin ve Keçeli, 2015). Mekansal algı zihin haritaları ile ölçülmeye çalışılmaktadır (Aksoy ve Hakan, 2012). Zihinsel bir harita, bireylerin mekansal eğilimlerini yansıttığ için mekansal olarak organize edilmiş tercihler olarak tanımlanır. Zihinsel haritalama, davranışsal coğrafyanın temel kavramlarından biri olarak, birçok yorumla algıları analiz ve temsil etmek ve tanımlamak için yararlı bir tekniktir. Aynı zamanda turistlerin destinasyon hakkındaki düşünceleri konusunda yararlı bilgiler sağlama fırsatı sağlamaktadır (Lee, Hitchcock ve Lei, 2018).

Destinasyon seçiminde hedef hakkında sahip olunan bilgilerin kapsamlılı̆̆ çok önemlidir. Çünkü bu bilgi bireyde, hedefin bir görüntüsünü üretir ve seyahat kararı konusunda yönlendirici güce sahiptir. Bu bilgilerden bir bölümü deneyimler sonucu elde edilirken, diğer kısmını ise pazarlama ve tanıtım çabaları sonucu oluşur (Moore, Simmons ve Fairweather, 1998). Bu çalışmanın amacı, destinasyon imajlarının nasıl oluştuğunu ve bu imajların destinasyonların gelişiminde etkisini ortaya koymaktır.

\section{KAVRAMSAL ÇERÇEVE}

\section{Davranışsal Coğrafya}

Davranışsal coğrafya, coğrafi alan bilgisinin beyinde nasıl temsil edildiğini, insanların yeni bilgileri nasıl elde ettiklerini ve bu süreçte coğrafi bilgi kaynaklarının rollerini inceler (Mark, Freksa, Hirtle, Lloyd ve Tversky, 1999). Çevreyi nasıl algıladığımız ve düşüncelerimiz ile algılarımızın düşüncelerimizi nasıl etkilediğinin incelenmesi davranışsal coğrafyanın konusunu oluşturmaktadır. Başka bir ifadeyle nerede 
yaşayacağımız, nereden alıveriş yapacağımız, nereleri ziyaret edeceğimiz gibi kararlar bizim yerler hakkındaki iyi-kötü, güzel-çirkin, güvenli-güvensiz gibi algılarımıza bağlıdır (Tümertekin ve Özgüç, 2007). Dolayısıyla davranışsal coğrafya, insanların çeşitli çevrelere tepkilerinin geniş ölçüde onları nasıl algıladığı ve anladığına bağlı olduğunu esas alan yaklaşımdır (Aliağaoğlu, 2007; Südaş ve Öz, 2018). Algı, imaj, mekân algısı ve zihin haritaları davranışsal coğrafya ile birlikte coğrafi literatürde yer edinmiş terminolojiler arasında sayılabilir. Mekân farklı ölçeklerde ele alınan bir kavram olup bir ülke olabildiği gibi bir kıta ya da bir mahalle de olabilmektedir. Kişisel ya da kültürel özelliklere göre mekanlar her birey tarafından farklı algılanmaktadır. Lefebvre (1991)'nin algılanan, yaşanan ve tasarlanan mekân üçlemesi, mekân ve mekân algısı çalışmalarına önemli bir altlık oluşturmuştur. Tasarlanan mekân fiziksel mekân olarak da adlandırılmaktadır. Yaşanan mekân ise aslında toplumsal mekândır ve insanların sosyal hayatlarının örüntülerinin gerçekleştiği alanlardır. Algılanan mekân, insanların öğrenim, kazanım ve tecrübeleri doğrultusunda kendi zihinlerinde oluşturdukları mekânlardır (Temurçin ve Keçeli, 2015). Davranışsal coğrafyanın ilgi odağ1 olan "subjektif mekânın" gözle görülebilir hale getirilmesinin temel araçlarından biri bilişsel (zihinsel) haritalardır.

\section{Zihin Haritaları}

Zihin haritaları ya da "bilme - öğrenme", haritaları, insanların kendi mekânsal çevreleri hakkında bilgi birikimleri, bu bilgilerin hafızada tutulması, yeniden hatırlanması ve gerekiyorsa bilgileri değiştirmeyi mümkün kılan bilme-öğrenme süreçleriyle kuşatılmış yapılardır. Kişiye özel tasvire dayalı bu harita gerçek değil, tamamen bireylerin mekân üzerinde bildikleri doğal ve beşerî unsurların bireylere göre değişken bir temsilidir (Aksoy ve Hakan, 2012; Karadağ ve Turgut, 2013).

Zihinsel bir harita, mekânsal olarak organize edilmiş tercihler olarak tanımlanır çünkü bireylerin mekânsal eğilimlerini yansıtır. Zihinsel haritalama, turizm araştırmalarında davranışsal coğrafyanın temel kavramlarından biri olarak, algıları birçok yorumla analiz etmek, temsil etmek ve tanımlamak için yararlı bir tekniktir (Lee vd., 2018).

Bilişsel haritalama, bireyin coğrafi çevrenin zihinsel bir temsilini oluşturma yeteneğine işaret eder. Bu temsil birden fazla şekilde oluşturulabilir. Örneğin, bir birey bilişsel olarak çevre ile doğrudan deneyim yoluyla zihinsel bir temsil oluşturabilir. Bu süreçte, bir kişi belirli bir alanı ziyaret eder ve yavaş yavaş bu ortamdaki yerler ve rotalar hakkında bir bilgi tabanı oluşturur. Bireyler ayrıca dolaylı yollarla bilişsel haritalar geliştirebilirler. Örneğin, kişilerden edindikleri mekânsal bilgiler yoluyla, eğitim yoluyla, sosyal medya yoluyla, internet siteleri, kitaplar, vb. kaynaklardan elde edilen bilgiler de zihinsel haritalara katkı sağlar (Lankford vd., 2005).

İnsanlar, yaşadıkları mekânı hatta daha geniş kapsamlı ele alınacak olursa dünyayı, birbirinden çok değişik boyutlarda algılar ve kavrarlar. Bu farklılaşma bireylerin yaşları, ilgileri, eğitim seviyeleri, zihinsel kapasiteleri, yaşadıkları ortamdaki uyaranlar vb. gibi birbirinden farklı ve çeşitli faktörlere bağlı olarak belirir (Alessandretti, Lehmann ve Baronchelli, 2018). 
İnsanların coğrafi mekanlarda gördükleri son derece çeşitlidir ve her insanın gördüğü kendine hastır. Zihnimizdeki resimler genellikle arazinin temsili görüntüsüdür, ayrıca, sesler, kokular ve hatta duyguları da içerirler. Algının özel bir şekli olan zihin haritaları, kâğıt ve kalem olmaksızın zihnimizde oluşturabildiğimiz şemalardır. Her birey zihninde bir dünya algısına sahiptir, hatta bu algının içinde henüz görmediği yerler de vardır (Tunçel, 2002). Bireylerin günlük hayatlarında yaptı̆̆ı rutin işlerin planlamasında, kısa ve uzak mesafeler için yapılan rota seçimlerinde zihinlerde oluşturulan bu mekânsal algılama etkili olmaktadır (Akbaş ve Toros, 2016). Bilişsel haritalar, daha önce bilinmeyen ortamların nasıl öğrenildiğini, yorumlandığını ve daha sonra nasıl kullanıldığını anlamaya yardımcı olarak, turist davranışına önemli bilgiler sağlar (Walmsley ve Jenkins, 1992). Bilişsel haritaları ve kaynaklarını öğrenmek hedef kitle için değiştirilebilir davranışlar konusunda destinasyonlara yardımcı olacaktır (Kong, 1991). Bu değerlendirmeler, destinasyonların turizm pazarındaki konumlarını ve rakiplerine göre durumlarını ortaya koyması açısından turizmciler açısından oldukça değerlidir (Walmsley ve Young, 1998).

\section{Destinasyon İmajı}

Her bireyin ihtiyaçları, arzuları, deneyimleri, yaş ve cinsiyetleri ile burada ifade edilmeyen daha birçok faktörün etkisiyle şekillenen kendi özel bir coğrafyası vardır. Dünya konusunda her bir imaj ve fikir kişisel deneyim, öğrenme, hayal ve belleğin sonraki bileşkesidir. İçinde yaşadığımız, ziyaret ettiğimiz ve seyahat ettiğimiz yerler, okuduğumuz dünyalar, sanat çalışmalarında gördüklerimiz, hayal alemleri ve fantezilerin her biri bizim beşerî ve doğal imajımıza katkıda bulunur (Aliağaoğlu, 2007).

İnsanların zihninde oluşan imaj, tatil destinasyonlarının seçiminde önemli bir etken olarak gösterilmektedir. Bu manada turist hareketlerinin daha iyi açılanması için bilişsel rota seçim kararlarını incelemek önem taşımaktadır. Bir yerin imajı, o yerin hem algısal / bilişsel hem de duygusal değerlendirmelerinin bir sonucu olarak oluşur. Yine ek olarak zevkler, inançlar, medya aracılığıyla tanıtım çabaları ve sosyal uyaranlar (arkadaşların ve akrabalarının önerileri veya kişilerin mekân hakkında aktardıkları) imaj oluşumuna katkı sağlarlar. Turistler seyahat etme arzusuyla bu kaynaklar dışında aktif bir bilgi aramasına katılabilir ve belirli ek bilgi kaynaklarına başvurabilirler. Turizm davranışını ve hedef seçim sürecini anlamak için bunları ortaya koymak önem taşımaktadır. Çünkü bunlar tüm eylemlerin arkasındaki çekici ve itici motivasyonlardır. Bir destinasyonunun imajı, aranan turistik motivasyonla büyük ölçüde ilişkilidir. Turistler ziyaretten önce ve sonra destinasyon imajı belirlerler. Hedef seçim sürecinde oluşturulan imajla ziyaret sonrası oluşan imajın benzer olması sürdürülebilirlik açısından önem taşımaktadır (Baloğlu ve McClearly, 1999).

Bir turizm destinasyonunun imajının güçlü veya zayıf olup olmadığını belirtmek için imageability terimi kullanılmaktadır. Imageability fiziksel bir nesnenin kalitesi olarak da tanımlanabilir. Özel bir şekle, renge veya bileşime sahip benzersiz, kolayca tanınabilir öğeler, bir kişinin zihnindeki en güçlü görüntüleri oluşturur. Turistler, 
turistik yere geldiğinde zihinsel haritalar gerçeklikle eşleştirilecektir. Diğer bir deyişle, bilişsel karar verme, seyahat gerçekleşmeden önce ve seyahatin kendisi sırasında gerçekleşir. Turistik seyahat öncesinde bir resim oluşturulur ve ilgili zihin haritası yapılır. Daha sonra, bu harita duyguların da rol oynayacağı gerçeklikle eşleştirilecektir (Jansen, 2011). Bu sebeple turistler seyahat edecekleri bölgelerde hangi özellikleri aramaktadır sorusu oldukça önemlidir. Seyahat öncesinde geniş bir başlangıç kümesi oluşturulmakta, daha sonra aranan özelliklere göre destinasyonlar elenmekte ve nihai bir hedef belirlenmektedir (Ankomah vd., 1996). Tatil planı yapıldığında insanlar kendilerine seyahat beklentilerine uygun sorular sorarlar. Örneğin kültür turizmi için hangi şehre gitmeliyim? Bu amaç doğrultusunda hedef bölgeler arasında bir derecelendirme yapılır ve tatil kararı verilir. İşte bu noktada havuza farklı sorular (Bu destinasyonda başka ne yapabilirim? Deniz var mı? Temiz mi? Destinasyon güvenli mi?) ekleneceği için bilişssel haritalar devreye girer. Bilişsel bir harita, mekanların öznel bir temsilidir (Moore vd., 1998). Bu nedenle tek bir dünya olmasına rağmen her bir bireyin zihninde faklı dünya imajları ve mekân temsilleri mevcuttur. Zihinlerdeki mekânsal imajlar deneyime dayalı olarak oluştuğu gibi günümüzde teknolojinin gelişmesiyle birlikte hiç gitmediğimiz ya da kişisel olarak deneyimlemediğimiz mekânlara ulaşabilme imkânı, dünyanın zihinlere daha geniş ölçeklerle yansımasına olanak sağlamaktadır (Köşker, 2019).

\section{YÖNTEM}

\section{Örneklem ve Veri Toplama Tekniği}

Master Card tarafından açıklanan Global Destination City Index 2019'a göre dünya üzerinde en fazla turist ziyareti elde eden 10 şehirden ikisi Türkiye'de olup İstanbul 8. ve Antalya 10. siradadır. Bu şehirlerin destinasyon imajını yabanc1 turistler perspektifinden incelemek önemlidir. Bu noktada araştırmanın sorusu "İstanbul ve Antalya'yı ziyaret etmiş ve etmemiş yabancı turistlerin, bu şehirlerin imajına yönelik görüşleri nelerdir?" olarak belirlenmiştir. Örneklem olarak ise dünyanın en gelişmiş ülkelerinden biri olan fakat Türkiye turizm pazarında önemli paya sahip olmayan Amerikalı bireyler seçilmiştir. Örnekleme yöntemi olarak basit tesadüfi örnekleme yöntemi tercih edilmiştir.

Araştırmada nicel yöntem kullanılmış olup veri toplama tekniği olarak anket kullanılmıştır. Anket formunun hazırlanmasında destinasyon imajı ile ilgili yapılan farklı çalışmalardan (Özaltaş Serçek ve Serçek, 2017; Öztürk ve Şahbaz, 2017; Koçoğlu, 2019; Ön Esen ve Bahar, 2019; Ünal ve Caber, 2019; Zengin, Hocaoğlu Bahadır ve Vatansever Toylan, 2019) yararlanılmıştır. Hazırlanan ankette İstanbul ve Antalya'nın destinasyon imajını oluşturan unsurlara yönelik iki ayrı ölçek ve İstanbul ve Antalya'yı ziyaret etme durumunda yaşanacak olası durumlara yönelik algıyı belirlemeye yönelik iki ayrı ölçek yer almaktadır. Anket formunda kullanılan ifadeler 1: Kesinlikle Katılmiyorum, 2: Katılmiyorum, 3: Ne Katıliyorum Ne Katılmiyorum, 4: Katılıyorum ve 5: Kesinlikle Katılıyorum olmak üzere beşli Likert ile derecelendirmiştir. Ayrıca, ifadelerle ilgili herhangi bir deneyimi veya fikri olmayan katılımcıların olabileceği düşüncesiyle seçeneklere 6: Fikrim Yok seçeneği eklenmiştir 
ancak bu seçeneği işaretleyen katılımcıların anketleri analizlere dahil edilmemiştir. Hazırlanan anket formu Amazon Mekanik Turk çevrimiçi veri toplama sitesine yüklenmiştir. Amazon Mekanik Turk 100'den fazla ülkeden 100 bin kişinin kayıtlı olduğu, demografik çeşitlilik içeren güvenilir bir platform (Rouse, 2015; Burhmester vd., 2011) olarak araştırmalarda veri toplama kaynağı olarak kullanılmaktadır (Peer, Vosgerau ve Acquisti, 2014; Cheung, Burns, Sinclair ve Sliter, 2017). Veriler 1-5 Temmuz 2020 tarihleri arasında toplanmıştır. Toplamda 437 adet anket toplanmış, eksik ve hatalı yanıtlanmış anketler elendikten sonra 416 anket (224 erkek ve 192 kadın) analize uygun bulunmuştur.

Verinin analizinde tanımlayıcı istatistiklerden ve Tek Yönlü Varyans Analizinden yararlanılmıştır. İstanbul ve Antalya'nın destinasyon imajı ile İstanbul ve Antalya'yı ziyaret etme durumunda yaşanabilecek olası durumlara yönelik turistlerin görüşlerini belirlemek için tanımlayıcı istatistikler kullanılmıştır. İstanbul veya Antalya'yı ziyaret etmiş veya etmemiş turistlerin, bu şehirlerin destinasyon imajlarına yönelik algılarının farklılaşıp farklılaşmadı̆̆ını ortaya koyabilmek için “ $\mathrm{H}_{1}$ : İstanbul veya Antalya'yı ziyaret etmiş veya etmemiş turistlerin, bu şehirlerin destinasyon imajına yönelik algıları anlamlı farklılık göstermektedir" hipotezi oluşturulmuş ve hipotezin test edilmesi için Tek Yönlü Varyans Analizi kullanılmıştır. Elde edilen sonuçlar, bulgular kısmında açıklanmıştır.

\section{BULGULAR}

Ankette yer alan ölçeklere yönelik olarak uygulanan güvenirlik analizinin sonuçları Tablo 1'de verilmiştir.

Tablo 1: Kullanılan Ölçeklere Yönelik Güvenirlik Analizi Sonuçları

\begin{tabular}{ll}
\hline Ölçek & Cronbach Alpha Değeri \\
\hline İstanbul'un destinasyon imaj unsurları & 0.936 \\
\hline Antalya'nın destinasyon imaj unsurları & 0.951 \\
\hline İstanbul ziyaretinde yaşanabilecek olası durumlara yönelik algı & 0.695 \\
\hline Antalya ziyaretinde yaşanabilecek olası durumlara yönelik algı & 0.685 \\
\hline
\end{tabular}

Kullanılan ölçeklerin güvenirlik katsayısının 0.6'nın üzerinde olması nedeniyle kabul edilebilir sınırın üzerinde olduğu (Kılıç, 2016) ve ölçeklerin güvenilir olduğu söylenebilir.

Katılımcıların 290'1 Antalya veya İstanbul'u hiç ziyaret etmemiştir. 65 katılımcı sadece Antalya'yı, 31 katılımcı ise sadece İstanbul'u ziyaret etmiştir. 78 katılımcı ise Antalya veya İstanbul hakkında daha önce hiçbir şey duymamıştır. Bu veri çalışmaya farklı bir anlam kazandırmaktadır. Destinasyonu ziyaret eden turistlerin zihnindeki imaj, ziyaret öncesi edinilen bilgilerin tatil tecrübesi sonucu gerçeklikle eşleştirilmesiyle elde edilir. Fakat destinasyonları ziyaret etmemiş olanların zihinlerindeki imaj ve kaynağını öğrenmek doğru tanıtım ve imaj planlamaları açısından yön gösterici olacaktır. Çalışmada Antalya veya İstanbul'u daha önce hiç ziyaret etmemiş katılımcılara, bu şehirlerle ilgili nereden bilgi sahibi oldukları sorulduğunda 33'ü 
televizyonda yayınlanan haberlerden, 19'u eğitim kurumlarından, 20'si internet veya sosyal medyadan, 8'i aile veya arkadaşlarından, 2'si seyahat firmalarından ve 1'i gazete veya dergilerden bilgi edindikleri yanıtını vermiştir. 118 katılımcı ise sayılan kaynakların iki veya daha fazlasından bu bilgilere ulaştıklarını ifade etmişlerdir. Birden fazla kaynağı işaretleyen katılımcıların yanıtlarına bakıldığında televizyonda yayınlanan haberler ile internet ve sosyal medyanın öne çıktığ 1 belirlenmiştir.

Turistik destinasyon olarak İstanbul ve Antalya'nın imajlarına yönelik tanımlayıcı istatistikler Tablo 2' de verilmiştir.

Tablo 2: İstanbul ve Antalya'nın Destinasyon İmajlarına Yönelik Tanımlayıcı İstatistikler

\begin{tabular}{|c|c|c|c|c|c|c|}
\hline \multirow{3}{*}{ Destinasyon İmaj Unsuru } & \multicolumn{3}{|c|}{ İSTANBUL } & \multicolumn{3}{|c|}{ ANTALYA } \\
\hline & \multirow{2}{*}{$\mathrm{n}^{*}$} & Ortalama & Standart & \multirow{2}{*}{$\mathrm{n}^{*}$} & \multirow{2}{*}{$\begin{array}{l}\text { Ortalama } \\
\text { Değer }\end{array}$} & \multirow{2}{*}{$\begin{array}{l}\text { Standart } \\
\text { Sapma }\end{array}$} \\
\hline & & Değer & Sapma & & & \\
\hline $\begin{array}{l}\text { İstanbul'un/ Antalya'nın kültürel } \\
\text { çekicilikleri vardır. }\end{array}$ & 359 & 4.33 & 0.851 & 305 & 4.1 & 0.932 \\
\hline $\begin{array}{l}\text { İstanbul'un/ Antalya'nın eşsiz mimarisi } \\
\text { vardır. }\end{array}$ & 358 & 4.29 & 0.85 & 311 & 4.07 & 0.894 \\
\hline $\begin{array}{l}\text { İstanbul'un/ Antalya'nın tarihi } \\
\text { çekicilikleri vardır. }\end{array}$ & 363 & 4.28 & 0.863 & 311 & 4.11 & 0.866 \\
\hline $\begin{array}{l}\text { İstanbul'un/ Antalya'nın eşsiz binaları } \\
\text { vardır. }\end{array}$ & 361 & 4.27 & 0.89 & 305 & 4.08 & 0.946 \\
\hline $\begin{array}{l}\text { İstanbul'un/ Antalya'nın doğal } \\
\text { çekicilikleri ve güzellikleri vardır. }\end{array}$ & 353 & 4.16 & 0.843 & 308 & 4.07 & 0.872 \\
\hline İstanbul/ Antalya dindar bir şehirdir. & 346 & 4.12 & 0.923 & 275 & 3.85 & 1.014 \\
\hline $\begin{array}{l}\text { İstanbul'un/ Antalya'nın çeşitli alışveriş } \\
\text { imkanları vardır. }\end{array}$ & 354 & 4.1 & 0.88 & 291 & 3.95 & 0.947 \\
\hline $\begin{array}{l}\text { İstanbul'da/ Antalya'da fiyat açısından } \\
\text { uygun ve çeşitlilik gösteren konaklama } \\
\text { imkanları vardır. }\end{array}$ & 360 & 4.09 & 0.897 & 299 & 4.02 & 0.908 \\
\hline $\begin{array}{l}\text { İstanbul'un/ Antalya'nın yerel } \\
\text { festivalleri vardır. }\end{array}$ & 326 & 4.04 & 0.926 & 286 & 3.96 & 0.915 \\
\hline $\begin{array}{l}\text { İstanbul'un/ Antalya'nın iyi bir gece ve } \\
\text { eğlence hayatı vardır. }\end{array}$ & 349 & 4.02 & 0.887 & 285 & 3.97 & 0.947 \\
\hline $\begin{array}{l}\text { İstanbul'un/ Antalya'nın iyi bir iklimi } \\
\text { vardır. }\end{array}$ & 340 & 4 & 0.881 & 291 & 3.95 & 0.956 \\
\hline İstanbul/ Antalya kalabalık bir şehirdir. & 352 & 3.98 & 0.937 & 283 & 3.72 & 1.07 \\
\hline $\begin{array}{l}\text { İstanbul'da/ Antalya'da yeterli toplu } \\
\text { taşıma hizmeti vardır. }\end{array}$ & 330 & 3.95 & 1.002 & 277 & 3.77 & 0.984 \\
\hline $\begin{array}{l}\text { İstanbul'un/ Antalya'nın güzel plajları } \\
\text { vardır. }\end{array}$ & 323 & 3.94 & 1.038 & 288 & 4 & 0.899 \\
\hline $\begin{array}{l}\text { İstanbul'dan/ Antalya'da çeşitli doğa } \\
\text { aktivitesi imkanları vardır. }\end{array}$ & 333 & 3.94 & 0.946 & 288 & 3.93 & 0.959 \\
\hline $\begin{array}{l}\text { İstanbul'un/ Antalya'nın yeterli taksi } \\
\text { hizmeti vardır. }\end{array}$ & 310 & 3.93 & 0.913 & 274 & 3.94 & 0.912 \\
\hline
\end{tabular}




\begin{tabular}{|c|c|c|c|c|c|c|}
\hline İstanbul/ Antalya gürültülü bir şehirdir. & 344 & 3.92 & 1.013 & 279 & 3.54 & 1.14 \\
\hline $\begin{array}{l}\text { İstanbul/ Antalya altyapı açısından } \\
\text { kalitelidir. }\end{array}$ & 356 & 3.92 & 0.904 & 294 & 3.93 & 0.912 \\
\hline $\begin{array}{l}\text { İstanbul'un/ Antalya'nın alternatif } \\
\text { ulaşım (Uber gibi) imkanları vardır. }\end{array}$ & 309 & 3.85 & 1.005 & 262 & 3.86 & 0.986 \\
\hline $\begin{array}{l}\text { İstanbul'un/ Antalya'nın huzurlu ve } \\
\text { dinlendirici bir atmosferi vardır. }\end{array}$ & 352 & 3.85 & 0.96 & 297 & 4 & 0.876 \\
\hline İstanbul/ Antalya aile dostu bir şehirdir. & 346 & 3.83 & 1.017 & 291 & 3.95 & 1.009 \\
\hline $\begin{array}{l}\text { İstanbul/ Antalya yeterince hijyenik ve } \\
\text { temizdir. }\end{array}$ & 347 & 3.81 & 1.026 & 289 & 3.97 & 0.951 \\
\hline $\begin{array}{l}\text { İstanbul'da/ Antalya'da trafik sıkışıklığ } 1 \\
\text { vardır. }\end{array}$ & 327 & 3.78 & 1.005 & 269 & 3.62 & 1.068 \\
\hline $\begin{array}{l}\text { İstanbul/ Antalya engelli dostu/engelsiz } \\
\text { bir şehirdir. }\end{array}$ & 321 & 3.76 & 1.078 & 270 & 3.81 & 1.003 \\
\hline $\begin{array}{l}\text { İstanbul/ Antalya çocuk dostu bir } \\
\text { şehirdir. }\end{array}$ & 331 & 3.73 & 0.999 & 281 & 3.84 & 1.026 \\
\hline $\begin{array}{l}\text { İstanbul'un/ Antalya'nın havası } \\
\text { kirlenmemiş bir çevre ortamı vardır. }\end{array}$ & 327 & 3.53 & 1.07 & 282 & 3.79 & 1.004 \\
\hline İstanbul/ Antalya sıkıcı bir şehirdir. & 353 & 2.81 & 1.353 & 297 & 3.04 & 1.32 \\
\hline
\end{tabular}

* Analize tabi tutulan anket sayısı n=416 olmasına karşın, Fikrim Yok seçeneğini işaretleyenler analize dahil edilmemiştir.

Tablo 2' de görüldüğü gibi katılımcıların verdiği yanıtlara göre en yüksek ortalamayı İstanbul'un kültürel çekicilikleri vardır ifadesi, en düşük ortalamayı ise İstanbul sıkıcı bir şehirdir ifadesi almıştır. Öte yandan İstanbul'un destinasyon imajına yönelik ankette bulunan ifadelere verilen yantların ortalamalarının çoğunlukla 3.5 ve üzerinde olduğu, gece ve eğlence hayatının iyi olması, uygun fiyatlı ve çeşitli konaklama imkanlarının olması, tarihi, kültürel ve doğal çekiciliklerinin olması, tarihi binalarının olması, yerel festivalleri ve alışveriş imkanlarının olması, iyi bir ikliminin olması ve dindar bir şehir olmasına yönelik ifadelerin ise 4 ve üzerinde ortalaması olduğu tespit edilmiştir. Öte yandan katılımcıların verdiği yanıtlara göre en yüksek ortalamayı Antalya'nın tarihi çekicilikleri vardır ifadesi, en düşük ortalamayı ise Antalya sıkıcı bir şehirdir ifadesi almıştır. Antalya'nın turizm imajında çok büyük pay sahibi olan kıyı ve deniz turizmine yönelik cevapların (Antalya'nın doğal çekicilikleri ve güzellikleri vardır, Antalya'nın güzel plajları vardır.) yanıt ortalamalarının kültürel çekiciliklerden çok sonra gelmesi dikkat çekicidir. Öte yandan Antalya'nın destinasyon imajına yönelik ankette bulunan ifadelere verilen yanıtların ortalamalarının çoğunlukla 3.5 ve üzerinde olduğu; uygun fiyatlı ve çeşitli konaklama imkanlarının olması, güzel plajları olması, kültürel ve doğal çekiciliklerinin olması ve huzurlu ve dinlendirici bir atmosferi olmasına yönelik ifadelerin ise 4 ve üzerinde ortalaması olduğu tespit edilmiştir.

Katılımcılara İstanbul'u ve Antalya'yı ziyaret etmeleri halinde karşı karşıya kalabilecekleri olası durumlarla alakalı yöneltilen ifadeler için alınan yanıtlara yönelik tanımlayıcı istatistikler ise Tablo 3'te verilmiştir. 
Tablo 3: İstanbul ve Antalya Ziyaretine Yönelik Algılarla İlgili Tanımlayıcı İstatistikler

\begin{tabular}{|c|c|c|c|c|c|c|}
\hline \multirow{3}{*}{ Destinasyon Algısı } & \multicolumn{3}{|c|}{ ISTANBUL } & \multicolumn{3}{|c|}{ ANTALYA } \\
\hline & \multirow{2}{*}{$\mathbf{n}^{*}$} & Ortalama & Standart & \multirow{2}{*}{$\mathbf{n}^{*}$} & \multirow{2}{*}{$\begin{array}{l}\text { Ortalama } \\
\text { Değer }\end{array}$} & \multirow{2}{*}{$\begin{array}{l}\text { Standart } \\
\text { Sapma }\end{array}$} \\
\hline & & Değer & Sapma & & & \\
\hline $\begin{array}{l}\text { İstanbul'a/ Antalya'ya } \quad \text { gidersem } \\
\text { güvende hissedebilirim. }\end{array}$ & 378 & 3.74 & 1.08 & 324 & 3.87 & 0.999 \\
\hline $\begin{array}{l}\text { İstanbul'a/ Antalya'ya gidersem } \\
\text { inancıma yönelik dini mekanları ziyaret } \\
\text { edebilirim. }\end{array}$ & 359 & 3.57 & 1.184 & 314 & 3.62 & 1.125 \\
\hline $\begin{array}{lll}\text { İstanbul'a/ } & \text { Antalya'ya } & \text { gidersem } \\
\text { soyulabilirim. } & & \end{array}$ & 356 & 3.42 & 1.154 & 310 & 3.32 & 1.22 \\
\hline $\begin{array}{l}\text { İstanbul'a/ Antalya'ya } \\
\text { kazıklanabilirim. }\end{array}$ & 361 & 3.4 & 1.104 & 314 & 3.37 & 1.201 \\
\hline $\begin{array}{l}\text { İstanbul'a/ Antalya'ya gidersem } \\
\text { hastalanabilirim. }\end{array}$ & 362 & 3.33 & 1.153 & 318 & 3.4 & 1.176 \\
\hline $\begin{array}{l}\text { İstanbul'a/ Antalya'ya } \quad \text { gidersem } \\
\text { kendimi evimde gibi hissedebilirim. }\end{array}$ & 372 & 3.31 & 1.23 & 312 & 3.43 & 1.196 \\
\hline
\end{tabular}

* Analize tabi tutulan anket sayısı n=416 olmasına karşın, Fikrim Yok seçeneğini işaretleyenler analize dahil edilmemiştir.

Tablo 3'te görüldüğü gibi katılımcıların İstanbul'a yönelik destinasyon algısında en yüksek ortalamaya sahip ifade İstanbul'a gidersem güvende hissedebilirim ifadesi, en düşük ortalamaya sahip ifade ise İstanbul'a gidersem kendimi evimde gibi hissedebilirim ifadesi olmuştur. Öte yandan İstanbul ziyaretlerinde hastalanma, kazıklanma ve soyulma gibi olumsuz ifadelere verilen yanıtların ortalamasının 3.4'ün altında olduğu tespit edilmiştir. Öte yandan katılımcıların Antalya'ya yönelik destinasyon algısında en yüksek ortalamaya sahip ifade Antalya'ya gidersem güvende hissedebilirim ifadesi, en düşük ortalamaya sahip ifade ise Antalya'ya gidersem soyulabilirim ifadesi olmuştur. Antalya ziyaretlerinde hastalanma ve kazıklanma gibi olumsuz ifadelere verilen yanıtların ortalamasının da 3.4'ün altında olduğu tespit edilmiştir.

Araştırmanın temel sorusu olan “İstanbul veya Antalya'yı ziyaret etmiş ve etmemiş yabancı turistlerin, bu şehirlerin imajina yönelik görüşleri nelerdir?" sorusunun yanıtını verebilmek için "bu şehirlerin imajları, şehirleri ziyaret etmiş ve etmemiş turistler için nasıl farklılaşmaktadır" alt sorusu belirlenmiştir. Bu soruya yanıt bulabilmek için oluşturulan “ $\mathrm{H}_{1}$ : İstanbul veya Antalya'yı ziyaret etmiş veya etmemiş turistlerin, bu şehirlerin destinasyon imajına yönelik algıları anlamlı farklılık göstermektedir" şeklinde belirlenen hipotezin test edilmesi için Tek Yönlü Varyans Analizinden yararlanılmıştır. Tablo 4'te İstanbul'u ve Antalya'yı ziyaret etmiş ve ziyaret etmemiş turistlerin bu şehrin destinasyon imaj unsurlarına yönelik algılarının nasıl farklılaştığını belirlemeye yönelik olarak yapılan Tek Yönlü Varyans Analizinin sonuçları görülmektedir.

Tablo 4: İstanbul ve Antalya'yı Ziyaret Etmiş ve Etmemiş Turistlere Göre Destinasyon İmaj Algısının Farklılaşmasına Yönelik Tek Yönlü Varyans Analizi 


\begin{tabular}{|c|c|c|c|c|c|c|}
\hline $\begin{array}{l}\text { İstanbul } \\
\text { Destinasyon } \\
\text { İmaj1 }\end{array}$ & $\begin{array}{l}\text { Kareler } \\
\text { Toplamı }\end{array}$ & $\begin{array}{l}\text { Serbestlik } \\
\text { Derecesi }\end{array}$ & $\begin{array}{l}\text { Ortalamalar } \\
\text { Karesi }\end{array}$ & $\mathrm{F}$ & $\mathrm{p}$ & Sheffe \\
\hline Gruplar Arası & 8.017 & 3 & 2.672 & \multirow{3}{*}{9.538} & \multirow{3}{*}{0.000} & \multirow{3}{*}{$\begin{array}{l}\text { İstanbul veya Antalya'yı hiç } \\
\text { ziyaret etmeyenlerin algısı, } \\
\text { şehirlerden en az birini } \\
\text { ziyaret edenlere göre daha } \\
\text { düşüktür. }\end{array}$} \\
\hline Grup İçi & 55.759 & 199 & 0.280 & & & \\
\hline Toplam & 63.776 & $202^{*}$ & & & & \\
\hline $\begin{array}{l}\text { Antalya } \\
\text { Destinasyon } \\
\text { İmaj1 }\end{array}$ & $\begin{array}{l}\text { Kareler } \\
\text { Toplamı }\end{array}$ & $\begin{array}{l}\text { Serbestlik } \\
\text { Derecesi }\end{array}$ & $\begin{array}{l}\text { Ortalamalar } \\
\text { Karesi }\end{array}$ & $\mathrm{F}$ & $\mathrm{p}$ & Sheffe \\
\hline Gruplar Arası & 8.943 & 3 & 2.981 & \multirow{3}{*}{8.261} & \multirow{3}{*}{0.000} & \multirow{3}{*}{$\begin{array}{l}\text { İstanbul veya Antalya'yı hiç } \\
\text { ziyaret etmeyenlerin algısı, } \\
\text { şehirlerden en az birini } \\
\text { ziyaret edenlere göre daha } \\
\text { düşüktür. }\end{array}$} \\
\hline Grup İçi & 62.793 & 174 & 0.361 & & & \\
\hline Toplam & 71.736 & $177^{*}$ & & & & \\
\hline
\end{tabular}

* Analize tabi tutulan anket sayısı n=416 olmasına karşın, Fikrim Yok seçeneğini işaretleyenler analize dahil edilmemiştir.

Tablo 4'te görüldüğü üzere İstanbul veya Antalya'yı hiç ziyaret etmemiş turistlerin, bu şehirlere yönelik destinasyon imaj algısı; şehirlerden en az birini ziyaret etmiş turistlere göre daha düşük olarak belirlenmiştir. “ $\mathrm{H}_{1}$ : İstanbul veya Antalya' yı ziyaret etmiş veya etmemiş turistlerin, bu şehirlerin destinasyon imajına yönelik algıları anlamlı farklılı göstermektedir" hipotezi kabul edilmiştir. Bu noktada destinasyonları hiç ziyaret etmemiş turistlere yönelik yapılacak pazarlama çalışmalarının, destinasyon imaj algısı üzerinde etkili bir araç olabileceği düşünülebilir.

\section{TARTIŞMA, SONUÇ VE ÖNERİLER}

Turistlerin mekânsal bilgisinin herhangi bir şekilde geliştirilmesinin destinasyonun turistik hareketliliğini arttıracağı ve turizm pazarına hizmet eden işletmelerin gelişimine katkı sağlayacağı muhtemeldir (Walmsley ve Jenkins, 1992). Bu çalışmada Amerikalı bireylerin İstanbul ve Antalya'nın destinasyon imajına yönelik görüşleri ve bu destinasyonlara ait algıları araştırılmıştır. Elde edilen bulgulara göre her iki şehrin de destinasyon imajına ait unsurlar, beş üzerinden üç ve üzerinde ortalama almıştır. İstanbul'un destinasyon imajına yönelik en yüksek ortalamayı alan unsur kültürel çekiciliklerin varlığı iken Antalya'nın destinasyon imajına yönelik en yüksek ortalamayı alan unsur tarihi çekiciliklerin varliğı olmuştur. En düşük ortalamayı alan unsur ise her iki şehir için de şehirlerin sıkıcı olması olmuştur.

Bilgi kaynaklarının çeşitliliğinin (miktarının) algısal/bilişsel değerlendirmelere olumlu katkısı nedeniyle, destinasyonlar turistlerin birden fazla bilgi kaynağı kullanmalarını sağlamalıdır. Farklı türde bilgi kaynaklarının algısal/bilişsel değerlendirmeler üzerinde farklı derecelerde etkiye sahip olduğu kanıtlanmıştır. Turistik görünümlerin en önemli kaynakları kişilerarası iletişim ile yapılan tanıtımlardır. Bu sebeple her bir turistin hoş deneyim sağlamasının henüz ziyaret etmemiş bireylerin destinasyon hakkındaki zihinsel imajlarına olumlu katkı sağlayacağı unutulmamalıdır. Ziyaretçilerin hedef destinasyonlara hangi motivasyonla geldiği tespit edilmeli ve reklam temaları, bu motivasyonlara hitap ederek hedef imajı etkili bir şekilde 
oluşturmak ve sürdürmek için geliştirilmelidir. Turizm pazarındaki paylarını artırmak isteyen ülkeler hedef pazarlarının özelliklerini göz önünde bulundurmalı ve imaj geliştirme ve konumlandırma çabalarını belirli sosyodemografik ve motivasyon segmentlerine göre şekillendirmelidir (Baloglu ve McCleary, 1999).

Çalışmada katılımcıların 290'1 Antalya veya İstanbul'u hiç ziyaret etmemiştir. 65 katılımcı sadece Antalya'yı, 31 katılımcı ise sadece İstanbul'u ziyaret etmiştir. 78 katılımcı ise Antalya veya İstanbul hakkında daha önce hiçbir şey duymamıştır. Çalışmada Antalya veya İstanbul'u daha önce hiç ziyaret etmemiş katılımcılara, bu şehirlerle ilgili nereden bilgi sahibi oldukları sorulduğunda 33'ü televizyonda yayınlanan haberlerden 19'u eğitim kurumlarından, 20'si İnternet veya sosyal medyadan, 8'i aile veya arkadaşlarından, 2'si seyahat firmalarından ve 1'i gazete veya dergilerden bilgi edindikleri 118 katılımcı ise sayılan kaynakların iki veya daha fazlasından bu bilgilere ulaştıklarını ifade etmişlerdir. Bu sonuçlarda en önemli imaj kaynağ1 olarak televizyonda yayınlanan haberler, internet ve sosyal medya öne çıkmaktadır. Türkiye'nin bu platformlarda gerçekleştireceği tanıtım çalışmaları destinasyon imajına olumlu katkı sağlayarak ziyaretçi hedef seçimini etkileyebilecektir. Özellikle gerek kamu ve gerekse özel sektör turizm kuruluşlarının sosyal medya araçlarını doğru ve verimli kullanmaları bu kapsamda destinasyon tanınırlığına önemli fayda sağlayacaktır. Türkiye'de düzenlenen tüm uluslararası organizasyonların öncesi ve sonrasında paylaşılan tüm medya araçları düzenlenirken hedefe yönelik içerikler seçilmesine dikkat edilmelidir.

Antalya ve İstanbul'u ziyaret eden ve etmeyen kişilerden oluşan örneklemde her iki şehirde de insanların kendini güvende hissetmesi bu destinasyonlar adına olumlu bir imajdır. Türkiye'nin bulunduğu coğrafi bölgede yer alan siyasi belirsizliklerin ve zaman zaman Türkiye'yi de etkileyen terör vb. olayların turistlerin güvenlik algısını etkilemediği görülmektedir. Ayrıca İstanbul ziyaretlerinde kazıklanma ve soyulma gibi olumsuz ifadelere verilen yanıtların ortalamasının 3,4'ün altında, yine Antalya için Antalya'ya gidersem kazıklanabilirim ifadesinin 3,4'ün altında, soyulabilirim ifadesinin ise en düşük ortalamaya sahip olması her iki destinasyonun da şehir güvenliği açısından olumlu bir imaja sahip olduğunu göstermektedir.

Çalışmadaki sonuçların geneli yorumlandığında her iki şehrin de olumsuz imaja sahip olmadığ fakat aynı zamanda destinasyonlar hakkında sahip olunan bilginin de yeterli olmadığı görülmektedir. Türkiye'nin kıyı turizminde en önde gelen destinasyonlarından biri olan Antalya'nın Amerikalı bireyler üzerinde daha çok tarihi ve kültürel çekiciliklere dayalı bir imaj sahibi olması önemli bir eksiklik olarak öne çıkmaktadır. Türkiye'ye yönelik destinasyon imaj çalışmalarının arttırılması ve elde edilen sonuçlara göre tanıtım çalışmalarının planlanması gerekmektedir.

$\mathrm{Bu}$ çalışmanın, pek çok çalışmada olduğu gibi bazı kısıtlılıkları vardır. Birincisi araştırmanın sadece Amerikalı turistlere yönelik olarak yapılmış olmasıdır. İleride farklı milliyetlerden turistlerle benzer araştırmalara yapılarak daha genellenebilir sonuçlar elde edilebilir. İkinci kisıtlılık ise analize tabi tutulan verinin Amazon Mekanik Turk platformu üzerinden toplanmış olmasıdır. Bundan sonra yapılacak 
çalışmalarda farklı kaynaklardan veri toplanabilir. İleride yapılacak araştırmalarda destinasyon imajı ve destinasyon algısının destinasyon ziyaret niyeti üzerindeki etkisi incelebilir. Öte yandan farklı demografik özelliklerin destinasyon imajı ve alg1sı üzerinde anlamlı farklılık yaratıp yaratmadığı da araştırılabilir.

Hakem Değerlendirmesi: Dis, bağmsız.

Teşekkür: Katkılarından dolayı hakemlere teşekkür ederim.

Destek Bilgisi: Herhangi bir kurum ve/veya kuruluştan destek alınmamıştır.

Çıkar Çatışması: Çıkar çatışması yoktur.

Etik Onayı: Bu çalışmanın tüm hazırlanma süreçlerinde etik kurallara riayet edildiğini yazar(lar) beyan eder. Aksi bir durumun tespiti halinde Güncel Turizm Araştırmaları Dergisi'nin hiçbir sorumluluğu olmayıp, tüm sorumluluk makale yazar(lar)ına aittir.
Bilgilendirilmiş Onam Formu: Tüm taraflar kendi rızaları ile çalışmaya dâhil olmuşlardır. Etik Kurul Onayı: Ondokuz Mayıs Üniversitesi Sosyal ve Beşeri Bilimler Etik Kurulu 29.05.2020 tarihli 2020/330 karar ile onay alınmıştır.

Araştırmacıların Katkı Oranı: 1. yazar katkı oranı: $\% 100$.

Veri Kullanılabilirlik Beyanı: Araştırma verileri paylaşılmamıştır.

\section{KAYNAKÇA}

Akbaş, Y. ve Toros S. (2016). Sınıf Öğretmenliği Öğretmen Adaylarının Coğrafi Bilgi Kaynakları ve Zihin Haritalarındaki Dünya İmajları. Doğu Coğrafya Dergisi, 21, 201224.

Aksoy, B. ve Koç, H. (2012). Türkiye' de öğrenim gören lisans öğrencilerinin zihin haritasında Avrupa birliği algısı (Ankara ili örneği). Milli Eğitim Dergisi, 42(196), 107-123.

Alessandretti, L., Lehmann, S., ve Baronchelli, A. (2018). Understanding the interplay between social and spatial behaviour. EPJ Data Science, 7(1), 1-17. https://doi.org/10.1140/epjds/s13688-018-0164-6

Aliağaoğlu, A. (2007). Davranışsal Coğrafyaya Bir Örnek: Öğrenci merkezli Balıkesir Şehir İmaj1. Frrat Üniversitesi Sosyal Bilimler Dergisi, 17(1), 17-44.

Ankomah, P. K., Crompton, J. L., ve Baker, D. (1996). Influence of Cognitive Distance in Vacation Choice. Annals of Tourism Research, 23(1), 138-150.

Baloglu, S. ve McCleary, K. W. (1999). A model of destination image formation. Annals of Tourism Research, 26(4), 868-897.

Buhrmester, M. D., Talaifar, S., ve Gosling, S. D. (2018). An evaluation of Amazon's Mechanical Turk, its rapid rise, and its effective use. Perspectives on Psychological Science, 13(2), 149-154.

Cheung, J. H., Burns, D. K., Sinclair, R. R. ve Sliter, M. (2017). Amazon Mechanical Turk in Organizational Psychology: An Evaluation and Practical Recommendations. Journal of Business and Psychology, 32, 347-361. 
Jansen, H. J. (2011). Tourist Familiarity in Amsterdam-Route choice behaviour of (un)familiar domestic tourists within Amsterdam's inner city (Yayınlanmamış Yüksek Lisans Tezi). Utrecht Publishing \& Archiving Services, Netherlands.

Karadağ, A. ve Turgut, H. (2013). Üniversite Öğrencilerinin Kentsel Çevre Alg1sı Üzerine Bir Araştırma: İzmir Örneği. Coğrafi Bilimler Dergisi/Turkish Journal of Geographical Sciences, 11(1), 31-51.

Kılıç, S. (2016). Cronbach'ın Alfa Güvenirlik Katsayısı. Journal of Mood Disorders. 6(1), 47-48.

Koçoğlu, C. M. (2019). Destinasyona Yönelik Marka İmajı ve Marka Sadakati İlişkisinde Algılanan Destinasyon Kalitesinin Aracılık Rolü. Seyahat ve Otel İşletmeciliği Dergisi, 16(1), 34-47.

Kong, L. (1991). Mental Images of Foreign Places: The View from Singapore. Singapore Journal of Tropical Geography, 12(1), 44-51.

Köşker, N. (2019). Öğretmen Adaylarının Zihin/Taslak Haritalarına Göre Türkiye'nin Çevresindeki Ülkeler. Mehmet Akif Ersoy Üniversitesi Eğitim Fakültesi Dergisi, (50), 324-358.

Lankford, S. V., Scholl, K., Pfister, R., Lankford, J. ve Williams, A. (2005). Cognitive mapping: An application for trail management. Kelly Bricker (Ed.), içinde Proceedings of the 2004 Northeastern Recreation Research Symposium (s. 378-384). Gen. Tech. Rep. NE-326. Newtown Square, PA: US Department of Agriculture, Forest Service, Northeastern Research Station.

Lee, M. Y., Hitchcock, M. ve Lei, J. W. (2018). Mental Mapping and Heritage Visitors' Spatial Perceptions. Journal of Heritage Tourism, 13(4), 305-319.

Mark, D. M., Freksa, C., Hirtle, S. C., Lloyd, R. ve Tversky, B. (1999). Cognitive Models of Geographical Space. International Journal of Geographical Information Science, 13(8), 747-774.

Moore, K., Simmons, D. G., ve Fairweather, J. R. (1998). Visitor Decision Making, On-Site Spatial Behaviours, Cognitive Maps And Destination Perceptions: A Case Study of Kaikoura. Tourism Research and Education Centre (TREC), Lincoln University, Report No. 4.

Ön Esen, F. ve Bahar, O. (2019). Destinasyon İmajı, Turist Memnuniyeti ve Destinasyon Sadakati İlişkisi Açısından Afyonkarahisar'da Termal Turizm. Türk Turizm Araştırmaları Dergisi, 3(4), 949-963.

Özaltaş Serçek, G. ve Serçek, S. (2017). X, Y ve Z Kuşaklarındaki Turistlerin Destinasyon İmaj Algılarının Karşılaştırılması. Seyahat ve Otel İşletmeciliği Dergisi, 14(1), 6-19.

Öztürk, Y. ve Şahbaz, R. P. (2017). Algılanan Destinasyon İmajının Tekrar Ziyaret Niyeti ve Tavsiye Davranışı Üzerine Etkisi: Ilgaz Dağı Milli Parkı'nda Bir Araştırma. Journal of Tourism and Gastronomy Studies, 5(2), 3-18.

Peer, E., Vosgerau, J. ve Acquisti, A. (2014). Reputation as a Sufficient Condition for Data Quality on Amazon Mechanical Turk. Behavior Research Methods, 46, 1023-1031.

Rouse, S. V. (2015). A Reliability Analysis of Mechanical Turk Data. Computers in Human Behavior, 43, 304-307. 
Südaş, İ. ve Öz, İ. (2018). Davranışsal Coğrafyada Bilişsel Haritalar: Ege Üniversitesi Kampüsü Örneği. Türk Coğrafya Dergisi, (71), 81-92.

Temurçin, K. ve Keçeli, K. (2015). Bir Davranışsal Coğrafya Çalışması: Isparta Şehri Örneğinde Uluslararası Öğrencilerin Kentsel Mekân Algısı. Süleyman Demirel Üniversitesi FenEdebiyat Fakültesi Sosyal Bilimler Dergisi, (36), 1-22.

Tunçel, H. (2002). Türk Öğrencilerin Zihin Haritalarında İslam Ülkeleri. Fırat University Journal of Social Science, 12(2), 83-103.

Tümertekin, E. ve Özgüç, N. (2007). Beşerî Coğrafya İnsan, Kültür, Mekân. Çantay Kitabevi, İstanbul.

Ünal, C. ve Caber, M. (2019). Turist Rehberlerinin Mesleki Yeterliliklerinin Destinasyon İmajına ve Memnuniyetine Etkisi. Anatolia: Turizm Araştırmaları Dergisi, 30(1), 82-92.

Walmsley, D. J. ve Young, M. (1998). Evaluative Images and Tourism: The Use of Personal Constructs to Describe the Structure of Destination Images. Journal of Travel Research, 36(3), 65-69.

Walmsley, D. J. ve Jenkins, J. M. (1992). Tourism Cognitive Mapping of Unfamiliar Environments. Annals of Tourism Research, 19(2), 268-286.

Zengin, E., Hocaoğlu Bahadır, N. ve Vatansever Toylan, N. (2019). Destinasyon Kişiliği ve Destinasyon İmajı Algısı Arasındaki İlişkilerin Araştııılması: Aydın İli Örneği. Kırklareli Üniversitesi Sosyal Bilimler Dergisi, 3(1), 58-69. 